\title{
A RTYKU $\mathrm{TY}$ RECENZYJ NE
}

Odrodzenie i Reformacja w Polsce, LVIII 2014

PL ISSN 0029-8514

Maciej Ptaszyński

Instytut Historyczny

Uniwersytet Warszawski

\section{„Grzeczny dysydent"? O pracy Dariusza M. Bryćko, The Irenic Calvinism of Daniel Kataj (d. 1681). A Study in the History and Theology of the Polish-Lithuanian Reformation ${ }^{1}$}

Daniel Kałaj był ważną postacią w szeregach pastorów reformowanych drugiej połowy XVII stulecia. Marek Wajsblum, który poświęcił mu wiele miejsca na kartach swoich prac, pisał, że „nawet okoliczne duchowieństwo katolickie podobno żywiło dlań przychylne uczucia i niejeden zapewne szlachcic czy ksiądz katolicki mógł powtórzyć za wyimaginowanym rozmówcą Kałaja z jego [- - ] dialogu: «człek dobry, w sąsiedztwie naszym wzięty, w obcowaniu skromny, przystojny, w naukach biegły, w kazaniach ćwiczony, w dyskursach miły, w posiedzeniu wdzięczny, w usługach użyty, nic złego przeciw Kościołowi katolickiemu nie mówiący, oprócz tego, że Dissident i Minister, alias grzeczny»" 2 .

Ów ,grzeczny dysydent”, pochodzący z ewangelickiej rodziny o węgierskich korzeniach, odebrał staranne wykształcenie w gimnazjum w Bremie

1 Por. D. M. Bryćko, The Irenic Calvinism of Daniel Kataj (d. 1681). A Study in the History and Theology of the Polish-Lithuanian Reformation, Göttingen 2012, Vandenhoeck \& Ruprecht, Refo500 Academic Studies, 4, s. 157.

2 M. Wajsblum, Ex regestro arianismi: szkice z dziejów upadku protestantyzmu w Matopolsce, „Reformacja w Polsce”, IX-X, 1937-1939, s. 89-408, tu: s. 256. 
i na uniwersytecie we Franeker, aby po powrocie do Rzeczypospolitej objąć urząd diakona, a następnie pastora w małopolskim kościele reformowanym. Do historii przeszedł jednak nie ze względu na swój łagodny charakter, lecz w związku ze sprawą uprowadzenia katolickiej córki Anny Heleny Chrząstowskiej przez jej ewangelickich krewnych. Jako duchowny w dobrach Chrząstowskich Kałaj został oskarżony „ex regestro arianismi” i w 1669 r. skazany na infamię oraz konfiskatę majątku. Jak pisze Janusz Tazbir, „był to pierwszy w Rzeczypospolitej wyrok śmierci na ministra”3. Opinia ta, powtórzona w recenzowanej monografii (s. 30), jest prawdziwa, jeżeli nie brać pod uwagę duchownych Kościoła braci polskich ${ }^{4}$. Po wyrokach sądu kapturowego oraz trybunału (VII 1669 i VIII 1670) Kałaj musiał opuścić Koronę i ukrywał się na Litwie, następnie w Prusach Książęcych, by w 1672 r. otrzymać posadę w Gdańsku. Po kilku latach, zmieniwszy nazwisko na Mikołajewski, powrócił do Wielkiego Księstwa Litewskiego (1676), gdzie jako pastor w Kiejdanach został nawet superintendentem dystryktu żmudzkiego. Marek Wajsblum, a za nim Janusz Tazbir przypuszczali, że zmarł około 1681 r., ale Stanisław Tworek na podstawie synodaliów znajdujących się w Bibliotece Litewskiej Akademii Nauk w Wilnie wykazał, stało się to dopiero dziesięć lat później, w roku $1691^{5}$. Dariusz Bryćko poświęcił Danielowi Kałajowi rozprawę, której cel nigdzie nie został jasno przedstawiony. Sam Autor zamierza wykazać, iż "the Reformed faith had a longer-lasting impact on the Polish Reformed Church than has often been recognized" (s. 12). W trzystronicowym artykule, podsumowującym efekty prac nad spuścizną i działalnością Kałaja, Bryćko wyjaśniał: „Badana przeze mnie twórczość Daniela Kałaja sugeruje, że polski kalwinizm miał dłuższy wpływ niż to jest zazwyczaj przyjmowane, wykraczając w drugą połowę XVII w." ${ }^{\text {. }}$ Dla polskiego czytelnika mówienie o wpływie bez określenia, na co ten wpływ jest wywierany, jest dość enigmatyczne. Podobnie sformułowanie: „wyznanie reformowane miało wpływ na kościół reformowany” brzmi

3 J. Tazbir, Kataj Daniel, PSB, 11, 1964-65, s. 503.

4 Zob. M. Ptaszyński, Szlichtyng Jonasz, PSB, 48, 2012-13, s. 398-403.

5 Por. S. Tworek, Materiaty do dziejów kalwinizmu $w$ Wielkim Księstwie Litewskim w XVII wieku, OiRwP, XIV, 1969, s. 199-215.

6 D. M. Bryćko, Polski kalwinizm i irenizm w drugiej potowie XVII w. Wspótczesne wydanie i omówienie dzieta Daniela Kataja pt. „Przyjacielska rozmowa ministra ewangelickiego z księdzem katolickim", [w:] Reformacja w dawnej Rzeczypospolitej i jej europejskie konteksty, wyd. P. Wilczek i in., Warszawa 2010, Sub Lupa, s. 142-144. 
tautologicznie. Bryćko nieco precyzuje tę myśli we wstępie do omawianej książki, gdzie czytamy, iż przez ów „wpływ” rozumie zachowanie intelektualnej żywotności kalwinizmu w XVII w. mimo prześladowań (s. 11: „many assumed that this [persecution $]^{7}$ meant the intellectual death of the Polish Reformed community").

Nieco inaczej Bryćko ujmuje tę myśl w zakończeniu rozprawy, pisze bowiem: „Reformed orthodoxy had a longer-lasting impact on the Polish Reformed Church” (s. 136). Brzmi to ciągle niezbyt logicznie, bo próżno w pracy szukać definicji owej „reformowanej ortodoksji”. Przenikliwy czytelnik może wprawdzie domyślać się, że skoro „grzeczny dysydent” jest kluczową postacią myśli irenicznej, Autor zamierza podważyć znaczenie owego irenizmu, podkreślając przynależność Kałaja do nurtu ortodoksji reformowanej.

W świetle deklaracji Autora praca ma więc dwa cele: jednym jest podważenie tezy o „intelektualnej śmierci wspólnoty reformowanej w Polsce", a drugim - zakwestionowanie przyjętej interpretacji myśli Daniela Kałaja jako irenicznej czy irenistycznej. Wydaje się oczywiste, że cele te nie są ze sobą logicznie powiązane, jeżeli nie przyjmie się założenia, że irenizm był „intelektualną śmiercią", a tylko ortodoksja odznaczała się intelektualną wartością. Założenie to nie zostało przez Autora nigdzie explicite wyrażone, ale wynika z wypowiedzi odnoszących się do celów rozprawy. Rozważania Autora skupiają się w gruncie rzeczy jedynie na drugiej tezie, czyli irenicznej myśli Kałaja.

Swoje wywody ujął Bryćko w osiem rozdziałów. Pierwsze dwa zawierają bardzo ogólny zarys historiografii (s. 11-18) oraz szkic biograficzny poświęcony Kałajowi (s. 19-37). W dalszych częściach Autor przedstawia podstawę źródłową (rozdział trzeci, s. 38-49) oraz szczegółową analizę poglądów Kałaja. W czwartym rozdziale omówiono „potencjalne źródła” irenicznej myśli Kałaja (s. 50-70), w piątym - jego stosunek do Biblii (s. 71-82), w szóstym - doktrynę usprawiedliwienia (s. 83-99), siódmym - sakramentologię (s. 100-118), a w ósmym - eklezjologię (s. 119-135).

Ponieważ to rekonstrukcja teologii Kałaja jest główną częścią pracy, należy najpierw przedstawić najważniejsze wyniki analiz Bryćki. W ich świetle Kałaj okazuje się prawowiernym ewangelikiem reformowanym, choć niektóre jego sformułowania można uznać za kontrowersyjne.

Jeśli nie zaznaczono inaczej, wszystkie komentarze w cytowanych fragmentach pochodzą od autora omówienia. 
W centralnej kwestii debat konfesyjnych XVI-XVIII w., czyli zagadnieniu usprawiedliwienia przez wiarę, Kałaj obok prawowiernej koncepcji iustitia imputativa wspomina o zyskującej popularność iustitia inhaerens (s. 86-92). Również jeśli chodzi o zasługi (meritum), Kałaj zajmuje dość liberalne stanowisko, akceptując średniowieczną koncepcję meritum ex congruo (s. 95-99).

Najoryginalniejsza z pewnością była jednak jego eklezjologia. Jak należy oczekiwać, kościół to dla Kałaja wspólnota wierzących, przy czym teolog rozróżnia kościół ziemski („bojujący”) i kościół „triumfujący” w Chrystusie (s. 122-123). „Grzeczny dysydent” zauważa zarazem, że „lepiej być dobrym katolikiem aniżeli złym ewangelikiem” oraz że „siła będzie złych ewangelików potępionych, a siła dobrych katolików zbawionych"8. Ponadto, zdaniem Kałaja, różnice dzielące kościoły reformowany i ewangelicko-augsburski stanowią jedynie „adiaphora”, rzeczy drugorzędne, „do gruntu zbawienia nie należące”" . Sformułowania te tradycyjnie bywają cytowane jako dowód na ireniczny charakter pism Kałaja, Bryćko jednak słusznie zauważa, że kilka stron dalej Kałaj dodaje: „Kościół nasz ewanielicki [!] [--] jest naprawdziwszym, Bogu najmilszym i drogę do zbawienia napewniejszą i nabliższą pokazującym Kościołem" ${ }^{10}$ (s. 128-130). Poza tym „grzeczny dysydent” uważa papieża za antychrysta oraz implicite potępia nikodemizm (s. 135).

Analizy Autora trzeba uznać za przenikliwe i wyłożone dość jasno, mimo to rodzą one wiele wątpliwości, dotyczących podstawy źródłowej, przyjętych założeń metodologicznych oraz stosunku do historiografii.

Dorobek Kałaja był dość skromny, liczył bowiem zaledwie kilkanaście pozycji. Autor wymienił je w bibliografii, lecz wszystkie powyższe ustalenia poczynił, analizując wyłącznie jedno dzieło teologa: Rozmowe przyjacielska ministra ewangelickiego z księdzem katolickim. Licząca 104 strony Rozmowa ukazała się po polsku w 1671 r., a jej fragment został przedrukowany w antologii Filozofia i myśl spoteczna XVII wieku, za którą Autor cytuje fragmenty dzieła w ostatnim rozdziale (s. 119-135 - stąd pewna odmiana wyglądu przypisów w tej części książki). Ponieważ jest to źródło dobrze znane i wielokrotnie już omawiane, trudno uznać je za

\footnotetext{
8 Filozofia i myśl spoteczna XVII wieku, cz. 2, oprac. Z. Ogonowski, Warszawa 1979, PWN, s. 718.

9 Ibidem, s. 733-734.

10 Ibidem, s. 728.
} 
wystarczającą podstawę do nowych konstatacji, zwłaszcza w obliczu tak ambitnie sformułowanych zamierzeń.

Co więcej, również sposób stawiania pytań i formułowania wywodu nieraz wydaje się zastanawiający. Mimo że Rozmowa nie jest tekstem nieznanym, w rozdziale trzecim Autor dość obszernie zajmuje się kwestią - bezspornego - autorstwa oraz strukturą dzieła (s. 38-47). Nie porusza natomiast zagadnień mogących budzić wątpliwości. Pomija np. sprawę miejsca wydania Rozmowy, które przemilczano na stronie tytułowej dzieła. Autor zakłada, iż utwór napisano na Litwie i wydrukowano w Gdańsku (s. 138, 47 oraz 33, przyp. 70), choć np. Janusz Tazbir uważa, że Kałaj „wydał” Rozmowę na Litwie ${ }^{11}$. Czytelnik nie dowie się także, jak nazywa się biskup krakowski (np. s. 33, 40), któremu Kałaj dedykuje swój utwór. Autor zauważa, co prawda, że dedykacja biskupowi apologii przed oskarżeniami o arianizm dowodzi pewnej naiwności Kałaja (s. 47: „as being extremly hopeful (if not outright naive)"), ale nie rozwija tej konstatacji. Czy naprawdę reformowany duchowny był aż tak naiwny, by sądzić, że przekona katolickiego biskupa i pouczy katolickich czytelników (s. 33)? Innymi słowy, czy fakt, że w dialogu występuje ksiądz, a w dedykacji zwrócono się do biskupa, naprawdę musi oznaczać, iż adresatami dzieła są odbiorcy katoliccy?

Zagadnienie konstrukcji katalogu pytań prowadzi do kwestii o nieco szerszym znaczeniu - przyjętej terminologii i definicji pojęć badawczych. Jak już wspomniano powyżej na marginesie terminu „reformowana ortodoksja”, niektóre kluczowe pojęcia, którymi posługuje się Autor, pozostają niezdefiniowane lub niedoprecyzowane. Taki zarzut można sformułować pod adresem „irenizmu”. Na s. 50 Bryćko pisze: „The term «irenic» traditionally has been used to describe areas of agreement or compromise among Christian who have some perspective on the unity or peaceful relationship between various Christian churches". Ponieważ jest to niezwykle szeroka definicja, wyliczenie irenicznych autorów w Europie rozpoczyna się od św. Tomasza, a kończy je Pierre Jurieu. W Polsce do grona zwolenników irenizmu zaliczono Jana Łaskiego, Andrzeja Frycza Modrzewskiego, socynianów, Jana Amosa Komeńskiego i Valeriana Magni (s. 50-51). Już samo wskazanie przedstawicieli tak różnych obozów i zwolenników odmiennych kierunków porozumienia powinno skłonić do refleksji, że irenizm ma wiele twarzy i być może precyzyjniej

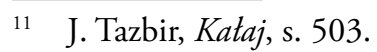


byłoby mówić o wielu „irenizmach”. Większa precyzja w definiowaniu tego terminu pozwoliłaby być może uniknąć takich sformułowań, jak np. „Łaski’s later ecumenical work among Frisian, English, Czech, and Polish Protestants" (s. 55), które są nie tylko ogólnikowe, co po prostu błędne w świetle ustaleń literatury przedmiotu ${ }^{12}$.

Narzucającym się zagadnieniem, które dzieliło przedstawicieli myśli irenicznej, jest ich stosunek do antytrynitarzy czy do uznania Kościoła rzymsko-katolickiego. Irenizm pełnił także różne funkcje, np. podczas wojny trzydziestoletniej bywał po prostu kwestią porozumienia wewnątrzprotestanckiego. W przypadku Kałaja, przebywającego na Litwie i szukającego nowej posady, ukazanie różnic między wyznaniem augsburskim i reformowanym jako „adiaphora” mogło otworzyć mu drzwi do kariery w wielowyznaniowym Gdańsku. Ponieważ w mieście obok luteranów i - powoli ustępujących - reformowanych coraz większe znaczenie zyskiwali również katolicy, taka interpretacja dzieła niemal sama się narzuca $^{13}$. Autor jej jednak nie dostrzega i nie próbuje wprowadzić takich rozróżnień, a przecież poznawczo znacznie bardziej wartościowe byłoby umieszczenie dzieła, które ukazało się w 1671 r., w jego bezpośrednim kontekście, niż rozpoczynanie ogólnych rozważań na temat myśli Erazma z Rotterdamu czy Jana Łaskiego. Praktyczną konsekwencją tak szerokiego ujęcia spektrum porównawczego rozprawy jest odnoszenie sformułowań Kałaja bezpośrednio do myśli Jana Kalwina, Henryka Bullingera czy Konfesji Sandomierskiej oraz przeciwstawianie ich uchwałom soboru trydenckiego. Szczególnie wyraźnie widać to w przypadku omawiania koncepcji iustitia inhaerens, którą Autor wiąże - oczywiście słusznie z kolokwium w Ratyzbonie z 1541 r. (s. 86-92). Jak jednak przyznaje, Kałaj nigdy nie cytuje owego kolokwium (s. 89). Czytelnik może sobie zadać pytanie, czy jest to przykład obserwowanego w Europie odrodzenia zainteresowania Kalwinem i Bezą w latach $1640-80^{14}$. Ani pytania, ani odpowiedzi nie znajdzie jednak na kartach omawianej pracy.

12 Np. O. Bartel, Jan Easki, Warszawa 1999, Neriton, s. 154-155.

13 Por. M. G. Müller, Zweite Reformation und städtische Autonomie im Königlichen Preußen: Danzig, Elbing und Thorn in der Epoche der Konfessionalisierung (1557-1660), Berlin 1997, Akademie Verlag, s. 138-140, 149; S. Kościelak, Katolicy w protestanckim Gdańsku: od drugiej potowy XVI do końca XVIII wieku, Gdańsk 2012, Wydawnictwo UG. 14 Por. J. Raitt, Metonymy and Relation in the Eucharistic Theology of Theodore Beza and its Reception in the Seventeenth Century, [w:] Théodore de Bèze, Réformateur et Homme de Lettres, ed. I. Backus, Paris 2006, Presses Universitaires de Frances, s. 295-307. 
Być może właśnie z winy braku głębszej refleksji nad pojęciem irenizmu do pracy wkradło się fundamentalne nieporozumienie, jakim jest mylenie Konfesji Sandomierskiej ze Zgodą Sandomierską. Kwestii Konfesji warto poświęcić nieco więcej miejsca ze względu na jej rolę w rozprawie. Na s. 51 Autor wylicza: „The most important Polish irenic documents of the era include the Confession of Sandomierz (1570), the Warsaw Confederation (1573), the Synod of Thorn (or Toruń, 1595), the Racovian Catechism (1605), and the Colloquium Charitativum (1645)". Czytelnik ponownie może być zaskoczony uznaniem za „dokumenty” zarówno aktów prawnych czy teologicznych, jak i synodów i kolokwiów. Co ważniejsze jednak, jak Bryćko sam przyznaje w wielu miejscach rozprawy, Konfesja Sandomierska była jedynie tłumaczeniem Confessio Helvetica Posterior Heinricha Bullingera (s. 56, 84, przyp. 8), do której po długiej dyskusji na synodzie w Sandomierzu dołączono w formie aneksu fragmenty z Confessio Saxonica Melanchtona (czyli kolejnej wersji luterańskiej Konfesji Augsburskiej) oraz fragmenty traktatów Jana Kalwina i Teodora Bezy na temat eucharystii. Przebieg synodu w Sandomierzu w 1570 r. był niezwykle burzliwy, ale reformowane wyznanie wiary bynajmniej nie zostało przyjęte przez braci czeskich i luteranów ${ }^{15}$. Decyzję o wspólnej konfesji odłożono do następnego synodu, a zgodzono się jedynie na Consensus, czyli porozumienie o uznaniu prawowierności ${ }^{16}$. Autor nie rozróżnia tych dwóch, zupełnie odmiennych dokumentów, co symbolicznie wyraża pomyłka w przypisie 42 na s. 56 (powtórzona

15 Opis przebiegu synodu w: Akta Synodów Różnowierczych, wyd. M. Sipayłło, Warszawa 1972, Wydawnictwo UW, t. 2, s. 251-304. Por. analizy w: J. Bidlo, Jednota bratrská v prvním vyhnaství, t. 2 [1561-1573], Praha 1903, Bursik and Kohout, s. 151-58; O. Halecki, Zgoda sandomierska 1570 r.: jej geneza i znaczenie w dziejach reformacyi polskiej za Zygmunta Augusta, Warszawa 1915, Gebethner i Wolff, s. 199-259; J. Lehmann, Konfesja sandomierska na tle innych wyznań, Warszawa 1937, s. 114-123; D. E. Jabłoński, Historia Consensus Sendomiriensis, Berlin 1731, s. 37-59.

16 Znane są dwa przekazy, rękopiśmienny i drukowany, które nieco się różnią. Rękopis w: Národní muzeum w Pradze, fragm. E.b.1, č. 31; wydanie na podstawie rękopisu w: Akta Synodów Różnowierczych, t. 2, s. 301-305. Druk: Consens in Fide et Religione Christiane, s. 1. 1586; Consens in Fide et Religione Christiane, Heidelberg 1605; wydania na podstawie wersji drukowanej: Die Synoden der Kirche Augsburgischer Konfession in Großpolen im 16., 17. und 18. Jahrhundert, hrsg. von G. Smend, Posen 1930, Luther-Verlag, s. 61-64; Reformierte Bekenntnisschriften, Bd. 3, T. 1, hrsg. von A. Mühling, P. Opitz, Neukirchen 2012, Neukirchener Theologie, s. 15-21. 
w bibliografii), gdzie tytuł artykułu Dariusa Petkūnasa The Consensus of Sandomierz zostaje przekręcony na The Confession of Sandomierz ${ }^{17}$.

Również interpretacje artykułów Konfesji budzą wątpliwości, wynikające z sygnalizowanego powyżej mylenia obu dokumentów. Analizując artykuł 21 Konfesji Sandomierskiej, poświęcony eucharystii, Bryćko zwraca uwagę na rozróżnienie między określeniami „prawdziwy”, „duchowny” i „sakramentalny” użytymi w odniesieniu do sakramentu. Autor uważa je za świadectwo zerwania z oryginałem Bullingera: „It departed significantly from Bullinger's original idea and described the sacrament as 'prawdziwy' (true or real), 'duchowy' (spiritual) and 'sakramentalny' (sakramental)” (s. 114-115). Swoje uwagi Bryćko popiera autorytetem Jerzego Lehmanna, Henryka Gmiterka i Dariusa Petkūnasa, dodając, że interpretacja Lehmanna odbiega od wniosków Gmiterka, ale sprawę słusznie rozstrzygnął Petkūnas.

Czytelnik może być nieco zaskoczony, bo sformułowanie „sakramentalny sakrament" jest tautologią - nie wiadomo tylko, czy winić za nią tłumacza Confessio Helvetica, czyli Krzysztofa Trecego, komentatora Jerzego Lehmanna, czy być może Dariusza Bryćkę. Uważna lektura artykułu 21 Konfesji przekonuje, że Bryćko miesza dwie kwestie, które są poruszane w tymże artykule: sposób obecności Chrystusa w eucharystii i sposób spożywania przez wiernych tego sakramentu. Opisując obecność Chrystusa, Konfesja posługuje się kilkakrotnie przysłówkiem „prawdziwie” (,jako prawdziwie na onej wieczerzy swojej Pana Krystus apostołom ciało i krew swoję ku pożywaniu podał, tak i dziś na każdej Wieczerzy Pańskiej, prawdziwie wszyscy wierni ciałem i krwią Jego bywają nasyceni”) ${ }^{18}$. Tego przysłówka brak w łacińskim oryginale, gdzie Bullinger posługuję się terminem „spiritualiter” („spiritualiter cibentur et potentur fideles") ${ }^{19}$. Jak przypuszcza Lehmann, tłumacz zastąpił przysłówek „spiritualiter” słowem „prawdziwie” „z intencją znalezienia platformy porozumienia z luteranami i braćmi czeskimi”"

17 Por. D. Petkūnas, The Consensus of Sandomierz: An Early Attempt to Create a Unified Protestant Church in 16th Century Poland and Lithuania, „Concordia Theological Quarterly”, LXXIII, 2009, s. 317-346.

18 Konfesja Sandomierska, kom. K. Długosz-Kurczabowa, Warszawa 1995, Wydawnictwo Naukowe Semper, s. 190-191.

19 Confessio Helvetica Posterior, [w:] Reformierte Bekenntnisschriften, Bd. 2, T. 2, s. 243-345.

20 J. Lehmann, Konfesja, s. 256, 260. 
Nie zmienił jednak sensu oryginału, co do czego zgodnie wypowiedzieli się Lehmann, Gmiterek i Petkūnas ${ }^{21}$. Określenie „prawdziwie” nie musiało bowiem oznaczać „cieleśnie” ani „materialnie”, lecz mogło równie dobrze znaczyć „duchowo”, ponieważ obecność na sposób duchowy była dla czytelników Konfesji również prawdziwa i realna.

W drugiej części artykułu o eucharystii mowa zaś o rozróżnieniu „sposobów pożywania”: cielesnego, duchowego i sakramentalnego. Co więcej, sposób „cielesny” jest jednoznacznie negowany: „albowiem nigdzie w Piśmie Świętym nie masz takowych słow i terminow o tej zacnej Świętości, żeby cieleśnie i materialnym sposobem Pana Krystusa wierni jeść mieli, chociaż prawdziwie ciało i krew Jego przyjmują"22. Odpowiada to dokładnie treści Confessio Helvetica Posterior, gdzie też mowa jest o tym, że „manducatio non est unius generis”, i gdzie rozróżnia się trzy rodzaje pożywania, by pierwszy z nich zaraz odrzucić $^{23}$. Uzasadnienie brzmi jednak nieco inaczej, bo Confessio stwierdza bardziej lakonicznie, że „neque nos credimus, corpus Christi manducari ore corporis corporaliter, vel essentialiter". Tam więc, gdzie Bullinger pisze jedynie o pożywaniu „ore corporis corporaliter, vel essentialiter”, tłumacz Konfesji, Krzysztof Trecy, opuszcza słówko „essentialiter”, a dodaje pleonastycznie: „cieleśnie i materialnym sposobem”. Ponadto Trecy uzupełnia sformułowanie Bullingera o uwagę: „prawdziwie ciało i krew jego przyjmują" odsyłającą do pozostałych dwóch sposobów „pożywania”, duchowego i sakramentalnego. Zarazem potwierdza postawioną wyżej tezę, że „prawdziwie” wcale nie oznacza „cieleśnie”. Zmiany te są dość znaczące, ale nie ingerują w sens artykułu.

Czyżby więc komentarz Jerzego Lehmanna wprowadził Autora w błąd? Rozdział pracy Lehmanna poświęcony artykułowi o Wieczerzy Pańskiej podąża jednak zarysowaną powyżej drogą ${ }^{24}$. Odesłania Bryćki do dzieła Lehmanna nie wskazują wszelako na strony, gdzie analizowany jest artykuł

21 Por. ibidem, s. 257; H. Gmiterek, Bracia czescy a kalwini w Rzeczypospolitej. Potowa XVI-potowa XVII wieku, Lublin 1987, UMCS, s. 88 (,jak słusznie wykazywał Lehmann”); D. Petkūnas, Holy Communion Rites in the Polish and Lithuanian Reformed Agendas of the 16th and Early 17th Centuries, Klaipeda 2007, Klaipedos Universitetas, s. 109. 22 Konfesja Sandomierska, s. 194.

23 Zob. Confessio Helvetica Posterior, s. 303-311. Por. E. Koch, Die Theologie der Confessio Helvetica Posterior, Neukirchen-Vluyn 1968, Neukirchener Verlag des Erziehungsvereins, s. 303-311.

24 Por. J. Lehmann, Konfesja, s. 255-258. 
21, lecz na fragmenty, w których omawiane są załączniki do Konfesji, czyli fragmenty Konfesji Saskiej oraz traktatów Kalwina i Bezy. Lehmann pisze tam między innymi: „umieszczenie artykułu Konfesji Saskiej faktycznie rozsadzało ramy kalwinizmu" - zdanie to nie dotyczy jednak tłumaczenia Konfesji Sandomierskiej, lecz załączników ${ }^{25}$. Źródłem pomyłki jest więc nie tylko ignorowanie treści Konfesji oraz Confessio Helvetica, lecz także wykorzystanie nieadekwatnych fragmentów rozprawy Lehmanna.

Stosunek do literatury przedmiotu jest ostatnim punktem, na który trzeba zwrócić uwagę. Podejście Bryćki do prac historyków sprowadza się albo do niemal bezrefleksyjnego podążania za ich ustaleniami, albo do przytaczania ich w sposób niejasny, co utrudnia zrozumienie opisywanych wydarzeń. W pierwszej części pracy (s. 19-36) Autor powtarza jedynie wcześniejsze ustalenia Marka Wajsbluma, wykorzystane w biogramie w Polskim Stowniku Biograficznym oraz w drobniejszych publikacjach Janusza Tazbira i Stanisława Tworka. Należy więc wyraźnie zaznaczyć, że te partie mają charakter wyłącznie odtwórczy, by nie powiedzieć nawet popularnonaukowy, a Autor nieraz zaciemnia obraz bardzo precyzyjnie odmalowany przez Wajsbluma i Tworka na podstawie źródeł archiwalnych.

Posłużmy się przykładem ordynacji Kałaja. Na s. 26 Autor stwierdza: „In May of 1653, at the Synod of Bełżyce, he finally was ordained (other sources suggest that he might have been ordained in 1652, or even in 1666 in Chmielnik)”. Autor nie wyjaśnia przyczyn rozbieżności między przekazami historycznymi, choć nie jest ona błaha. Dotyczy bowiem pytania, czy Kałaj po ordynacji czekał na wolną posadę, czy być może sprawował urząd przez wiele lat bez ordynacji lub czy był ponownie ordynowany. Zagadnienie to wykracza poza zwykłą biografistykę, a mówi wiele o położeniu zborów zrzeszonych w reformowanej Jednocie Małopolskiej. Sytuacja, w której ordynowany pastor nie może znaleźć parafii, oznaczałaby, że w Jednocie był w tym okresie nadmiar duchownych, a losami Kałaja nieszczególnie się interesowano. Przyzwolenie na pracę duszpasterską bez ordynacji mogłoby natomiast świadczyć o ogromnym braku rąk do pracy, a nawet słabości bądź wręcz upadku organizacji synodalnej. Powtórna ordynacja przy zmianie urzędu byłaby zaś europejskim ewenementem. Kwestie te Wajsblum i Tworek przedstawili, korzystając z małopolskich synodaliów, dziś znajdujących się między innymi w Archiwum Głównym Akt Dawnych, Dziale Rękopisów Biblioteki Uniwersyteckiej w Warszawie

25 Por. ibidem, s. 301. 
oraz Bibliotece Litewskiej Akademii Nauk w Wilnie. Uważna lektura tych źródeł i opracowań pozwoliłaby odpowiedzieć na przykład na pytanie o datę ordynacji duchownego.

Recesy synodów dowodzą, że Jednota niezwykle uważnie śledziła edukację i przygotowanie Kałaja do objęcia funkcji kościelnych ${ }^{26}$. U źródeł tego zainteresowania leżały nie tylko jego talenty, lecz także waga wydatków na wykształcenie przyszłego duchownego, które były traktowane jako inwestycja dystryktu krakowskiego. Do ostrożności mogły też skłaniać pewne kłopoty ze starszym bratem Kałaja, Michałem, który nieco wcześniej niż Daniel, bo w 1642 r., został wysłany do Franeker za pieniądze dystryktu lubelskiego ${ }^{27}$. Jak uważa Wajsblum, w przeciwieństwie do „grzecznego” Daniela - Michał okazał się czarną owca $^{28}$. Po powrocie, w 1648 r. Daniel Kałaj został zatrudniony w szkole w Wielkanocy i od czerwca 1649 r. jako „diakon” lub „katechista” brał udział w synodach dystryktu krakowskiego ${ }^{29}$. Decyzje o przeprowadzeniu ordynacji Kałaja na przyszłym synodzie całej prowincji podjął dystrykt krakowski w Okszy 21-23 czerwca roku $1652^{30}$. Ponieważ ordynacja miała się odbyć na synodzie prowincjonalnym, poinformowano o tym także dystrykty lubelski i bełski, a te wyraziły zgodę na swoim synodzie dystryktowym w Sławatyczach 18 lutego roku $1653^{31}$. Sprawę sfinalizo-

26 Por. BUW, Dział rękopisów, rkps 592, t. 2, k. 69ver.-73 (synod dystryktowy w Okszy, 14 VI 1647), tu: k. 71 (,i do drugiego alumna zboru krakowskiego D. Daniela Kałajego napisać, któremu PP Starszy Zboru Krakowskiego także na trzeci rok sumpt obmyśleć obiecują").

27 Por. AGAD, Archiwum Zamoyskich (dalej: AZ), sygn. 3156, s. 48 [=BUW, rkps 594, k. 19] (synod dystryktu lubelskiego w Biłgoraju, 16 V 1642).

28 Por. M. Wajsblum, Ex regestro, s. 246. Powtórzone w: S. Tworek, Kontakty alumnów kalwińskich prowincji matopolskiej z ośrodkami zagranicznymi do połowy XVIII wieku, „Annales Universitatis Mariae Curie-Skłodowska”, Sectio F, XX, 1965, s. 76-93, tu: s. 79. Fragment opublikowany ponownie, choć tym razem z błędem - zamieniono Daniela z Michałem - w: S. Tworek, Szkolnictwo kalwińskie w Matopolskiego i jego zwiazki z innymi ośrodkami w kraju i za granica w XVI-XVII w., Lublin 1966, UMCS, s. 396. 29 Por. BUW, rkps 592, t. 2, k. 83-86 (synod dystryktu krakowskiego w Okszy, 18-20 VI 1649), por. k. 86 (Kałaj wymieniony jako „diakon przy zborze Wielkanocnym”). Na późniejszych synodach w 1. 1649-1652 Kałaj jest określany jako „katechista”.

30 Por. BUW, rkps 592, t. 2, k. 100-102 (synod dystryktu krakowskiego w Okszy, 21-23 VI 1642), tu: k. 102.

31 Por. AGAD, AZ, sygn. 3156, s. 104-105 [=BUW, rkps 594, k. 49v] (delegacja dystryktu bełskiego i lubelskiego na konwokację prowincjonalną do Chmielnika, 18 II 
wano na synodzie prowincjonalnym w Bełżycach w maju tego roku ${ }^{32}$. Wówczas zapewne Kałaj został ordynowany, gdyż w spisie uczestników synodu przy nazwisku Kałaja postawiono skrót „X”, czyli ksiądz.

Kałaj z pewnością nie został więc ordynowany w 1652 r., choć po niemal trzydziestu latach w autobiografii zanotował, że pracował „w zborze szczepanowickim lat 18 począwszy ab anno 1652, mojej na synodzie prowincjalnym w Bełżycach wraz z ks. Rederem p.m. Danielem, inaugarycjej" ${ }^{33}$. Sędziwego ministra zwiodła po prostu pamięć. Na zakończenie tej części rozważań należy zaznaczyć, że na synodzie w Chmielniku w 1666 r. nie przeprowadzono żadnych ordynacji, a Kałaj był na nim obecny jako konsenior ${ }^{34}$. Nie wiadomo, dlaczego Autor kwestionuje opis wydarzeń zaprezentowany przez Wajsbluma, a zamiast sięgnąć do źródeł synodalnych - powołuje się na „other sources”, odsyłając do pracy Romana Darowskiego Szczepanowice nad Dunajcem, gdzie zwięźle, lecz poprawnie przedstawiono sprawę ordynacji Kałaja ${ }^{35}$.

Można zaanalizować więcej sądów Autora, które budzą zastrzeżenia (np. uznanie Disputatio ogłoszonej we Franeker za „doctoral dissertation”, s. 25). Jednak większość z tych wątpliwości rozwiewa rozprawa Wajsbluma, z której Autor czerpie pełnymi garściami. Takie odtwórcze i popularyzujące wykorzystanie historiografii nie wyszło pracy na dobre. Szczytem pomyłek i nieścisłości jest podanie w tytule książki roku 1681 jako daty śmierci Kałaja, mimo iż - jak wspomniano - pastor zmarł dopiero dziesięć lat później, a i rozważania Bryćki nad życiem Kałaja wychodzą poza rok 1684 (s. 35) ${ }^{36}$.

1653: „Zleca się Delegatom, aby in hoc passu zezwolili na ordynacją in S. Ministerium B. Redera i D. Kałaiego").

32 Por. BUW, rkps 592, t. 2, k. 104-108 (synod prowincjonalny w Bełżycach, 2-4 V 1653), tu: 107-108ver. („Na ordynację braciej z dystryktu krakowskiego brata Daniela Redera, brata Daniela Kałajego, z dystryktu sendomierskiego brata Andrzeja Hermanna, z dystryktu ruskiego brata Pawła Reisnera zezwala praesens synodus"). Brak tej konkluzji w: BUW, rkps 594, k. 50-51ver. (synod dystryktu lubelskiego, Bełżyce 29 IV-1 V 1653).

33 S. Tworek, Materiaty, s. 212.

34 Por. BUW, rkps 592, t. 2, k. 152-153ver.

35 Por. R. Darowski, Szczepanowice nad Dunajcem. Dzieje wsi katolickiej i gminy kalwińskiej, Kraków 1993, Wydział Filozoficzny Towarzystwa Jezusowego, Instytut Kultury Religijnej, s. 85 („W 1652 lub 1653 r. został ordynowany na ministra”), 88 („Ordynację na konseniora otrzymał Kałaj na synodzie prowincjonalnym w Chmielniku w pierwszych dniach października 1660 r.”).

36 Por. S. Tworek, Materiaty, s. 206. 
Podsumowując powyższy wywód, trzeba powtórzyć, że praca Dariusza Bryćki oparta jest na niezwykle wąskiej bazie źródłowej: spośród 11 wymienionych w bibliografii dzieł Kałaja, Autor analizuje tylko jedno, godne raczej obszernego artykułu niż monografii. Analiza teologicznych loci z pewnością jest pod wieloma względami trafna i interesująca, choć oderwana od kontekstu, w jakim wypowiedzi te są formułowane, oraz dość selektywna. Wiele ważnych wątków Autor pomija, jak na przykład odwołanie w Rozmowie do prawa do oporu zawartego w Artykułach Henrykowskich i łączenie go z Konfederacją Warszawską ${ }^{37}$. To główny cel rozprawy powinien podyktować selekcję analizowanych zagadnień, ten jednak sformułowany został dość niejednoznacznie.

Oprócz błędów wskazanych powyżej, lekturę utrudniają liczne powtórzenia (por. np. s. 23: ten sam fragment w tekście głównym i w przypisie; s. 104 i 105) oraz niezliczone literówki, występujące w niemal każdym polskojęzycznym cytacie. Przekręcane bywają nazwiska (np. Krzysztof Trecy ciaggle nazywany jest „Tracy”; pseudonim Marcina Łaszcza to „Jan Gurski" (tak na s. 31, przyp. 63), na s. 31-32, przyp. 64-67 figuruje on jako „Górski”). Z błędami przytaczane są polsko- niemiecko- i łacińskojęzyczne tytuły („Bibliografię roczników Reformacji w Polsce” ochrzczono (s. 12, przyp. 3) mianem „Biografii”; tytuł dzieła Kaia Eduarda Jordta Jørgensena błędnie podaje się na s. 12, przyp. 4; s. 52, przyp. 18; s. 148). Bryćko niepoprawnie cytuje nawet artykuł Marka Wajsbluma Ex regestro arianismi (s. 15, przyp. 15; poprawnie w bibliografii na s. 156). Historia polskiej reformacji napisana przez Stanisława Lubienieckiego - powstała zapewne w połowie lat sześćdziesiątych XVII w., wydana pośmiertnie w 1685 r. po łacinie, ale przetłumaczona na angielski przez Georga Huntstona Williamsa w 1992 r. - umieszczona zostaje w przypisach jako dorobek współczesnej polskiej historiografii między pracami Lecha Szczuckiego i Zbigniewa Ogonowskiego (s. 12-13, przyp. 5; s. 59, przyp. 54). Można wskazać wiele podobnych lapsusów.

Rozprawa w niewielkim stopniu wzbogaca wiedzę o dziejach sporów konfesyjnych XVII w., popularyzuje bowiem przede wszystkim ustalenia

37 [D. Kałaj], Rozmowa Przyiacielska, ministra ewanielickiego zxiedzem katolickim, s. 1 . 1671, Dedykacja: „A jesliby się co stało temu naprzeciwko / abo in personam Regis, tedy ab omni fide \& obedientia Regibus debita solvuntur subditi, abo in personam alicujus, vel aliquarum ex Civibus Regni, tedy przeciwko takim / pacis \& securitatis Dissidentium violatoribus, obiecują Status Regni, sub fide honore \& conscientia związani pro se \& succesoribus, powstać y znosić”. 
Marka Wajsbluma. Wąska baza źródłowa prowokuje do postawienia pytania, czy analityczny artykuł w czasopiśmie nie byłby lepszą formą przekazu nowych ustaleń Autora, odnoszących się w gruncie rzeczy do kilku zagadnień teologicznych. 